\title{
GENDER DOMINATION IN LOCAL NEWSPAPERS
}

\author{
Mariani Amri \\ Communication Studies, School of Humanities, President University \\ E-mail: marinathar1@gmail.com
}

\begin{abstract}
This study was held at Fajar and Tribun Timur offices in Makassar. This research is described through texts, discourse practice, and socio-cultural practice by using CDA (Critical Discourse Analysis) from Norman Faircloughs' model. The model includes textual level, discourse practice level, and socio-cultural practice level. The type of this research is qualitative approach. This approach tries to get closer to what is being studied, that is gender domination in Fajar and Tribun Timur daily newspapers. It aims at in-depth and holistic understanding of gender domination in newspapers. Its flexibility is well suited to make interpretation to describe the facts and the phenomena of gender in newspapers as the way they are based on the data found. The research aims; to identify the domination of gender in Fajar and Tribun Timur daily newspapers, to analyse how gender dominations are expressed in those daily newspapers, and to analyse the effect of gender domination on news stories in those newspapers. The result of this research shows that Fajar and Tribun Timur daily are still male dominated discourse in the news-making process which influences the news stories printed in those newspapers. Gender domination in Fajar and Tribun Timur daily newspapers as a discourse has been proven to affect our views on news stories text, news stories production, and socio-cultural practices.
\end{abstract}

Keywords : gender, newspapers, discourse analysis

ABSTRAK. Penelitian ini berlangsung di kantor harian Fajar dan Tribun Timur Makassar. Penelitian ini dijelaskan melalui texts, discourse practice, dan socio-cultural practice dengan menggunakan CDA (Critical Discourse Analysis) dari model Norman Fairclough. Model analisisnya mencakup textual level, discourse practice level, dan socio-cultural level. Penelitian ini menggunakan tipe penelitian kualitatif mengenai dominasi gender di surat kabar Fajar dan Tribun Timur. Tujuan penelitian ini adalah untuk mengidentifikasi dominasi gender di harian Fajar dan Tribun Timur, untuk menganalisis bagaimana dominasi gender ditampilkan dalam kedua surat kabar, dan menganalisis efek dominasi gender dalam pemberitaan harian Fajar dan Tribun Timur.Hasil penelitian ini menunjukkan harian Fajar dan Tribun Timur masih didominasi oleh laki-laki di dalam proses pembuatan berita yang mempengaruhi isi pemberitaan dalam kedua surat kabar tersebut. Dominasi gender di harian Fajar dan Tribun Timur sebagai discourse mempengaruhi pandangan kita dalam news stories text, news stories production, dan socio-cultural practices.

Kata kunci : gender, surat kabar, discourse analysis

INTRODUCTION

The world of press is exclusively male profession (Jurnal Perempuan, 2003). This expression is supported by Carter, Branston and Allen (1998) who summarized- the place of female journalists in day to day culture of most newsrooms which is still being defined with the predominantly male terms. Topics covered by male are politic, crime, finance, education, and upbringing, while by female are human interest, culture, and social policy which reproduces the public-private arenas division (First, 2002).

In comparison to Indonesia, in 1998, $P W I$ (Persatuan Wartawan Indonesia) noted that male journalists are also dominant in the world of press. There were 4,687 male journalists and 461 female journalists (Jurnal Perempuan, 2003). These ratios are referred to as domination of male journalists over female journalists significantly and should get good attention to news-workers within the newsmaking processes.
The phenomenon of gender in Makassar still needs more attentions. There are too many cases regarding gender imbalance in social life. According to Forum Pemerhati Masalah Perempuan (FPMP) South Sulawesi, violence of female reached 20 cases in 2003 and 48 cases in 2005. These cases rise more than $100 \%$ (Baso, 2007). Violence in raping, striking, and prostitution occur higher day to day and are printed in newspapers.

In fact, a media research in various countries found that more than $20 \%$ of the news items in any of participating countries ever concerned with female but the figure was much lower in most cases (First, 2002). Negative stereotype of female in Makassar are emotional, weak, coward, and fussy. These assessments are preserved by gender domination and patriarchal culture in society.

This qualitative research concerned with the dominations of gender in Fajar and Tribun Timur daily newspapers which have a great number of 
circulations and readers in Makassar, which can be a place of gender cycles with a lot of gender domination in it. This domination can influence the news stories in the process to choose certain issues which go on in the newsroom as a place of reporters, editors, chief editors and other staff to work to gather news to be published in newspapers.

In this research, news stories which are related to gender issues in Fajar and Tribun Timur daily newspapers are identified in four levels. Vocabulary can help to look at the choice of words used in news stories to present gender in a different category either in positive or in negative way in reality. Grammar can show the type of predicate and the participant's roles of gender in news stories either as a performer in active sentences or as a victim in passive sentences, and nominalisation that focuses on the activity of gender issues. Cohesion is analysed by looking at repetition, synonyms, antonyms and connecting words of various kinds related to gender issues. This is to analyse further either implicitly or explicitly other purposes and influences of gender in the text. Text structures are seen in the news stories to see which part in the text appears more than the other texts and to see the influence of journalist in the text.

Discourse practice refers to the production of messages that is news stories in Fajar and Tribun Timur daily newspapers. These can be seen from male and female journalists interaction in the newsroom to constitute gender relations in newspapers to utter their opinion or in the process of making decisions within news flow that will be a news story shared to the public, and journalists' point of views to see either the internal institution or external institution that influences the newsmaking process. In this case, linking organisation structure of newspapers and the positions of male and female journalists can explain decision maker point of view, experience, and perspective of newsworkers for male and female journalists in Fajar and Tribun Timur daily newspapers.

Sociocultural practice is related to gender activist's point of view about gender role and representation in Fajar and Tribun Timur daily newspapers which is influenced by gender domination and imbalance in news stories. Using discourse analysis in this research emphasises how the text in news stories produced in newsroom relates to the process of decision-making by male and female journalists, how to see the language as element to present reality from dominant group in newspapers, and what the gender activists view about news stories related to gender issues in newspapers. These are the linking of text, discourse practice, and socio-cultural practice which are trying to identify, to analyse, and to observe gender domination in Fajar and Tribun Timur daily newspapers.

\section{METHODOLOGY}

Discourse analysis is a methodology useful in answering many kinds of questions, both questions that linguists traditionally ask; such as questions about linguistic structure, language change, language acquisition ; and questions asked by people in other humanistic and social scientific disciplines, like social roles and relations, communication, and identity. Type of this research is qualitative approach. In analysing data, Norman Fairclough's model is suitable for this research because this method integrates text made from social relations and social context about gender domination in local newspapers in Makassar which can make social change. This research analyses texts, discourse practice, and socio-cultural practice.

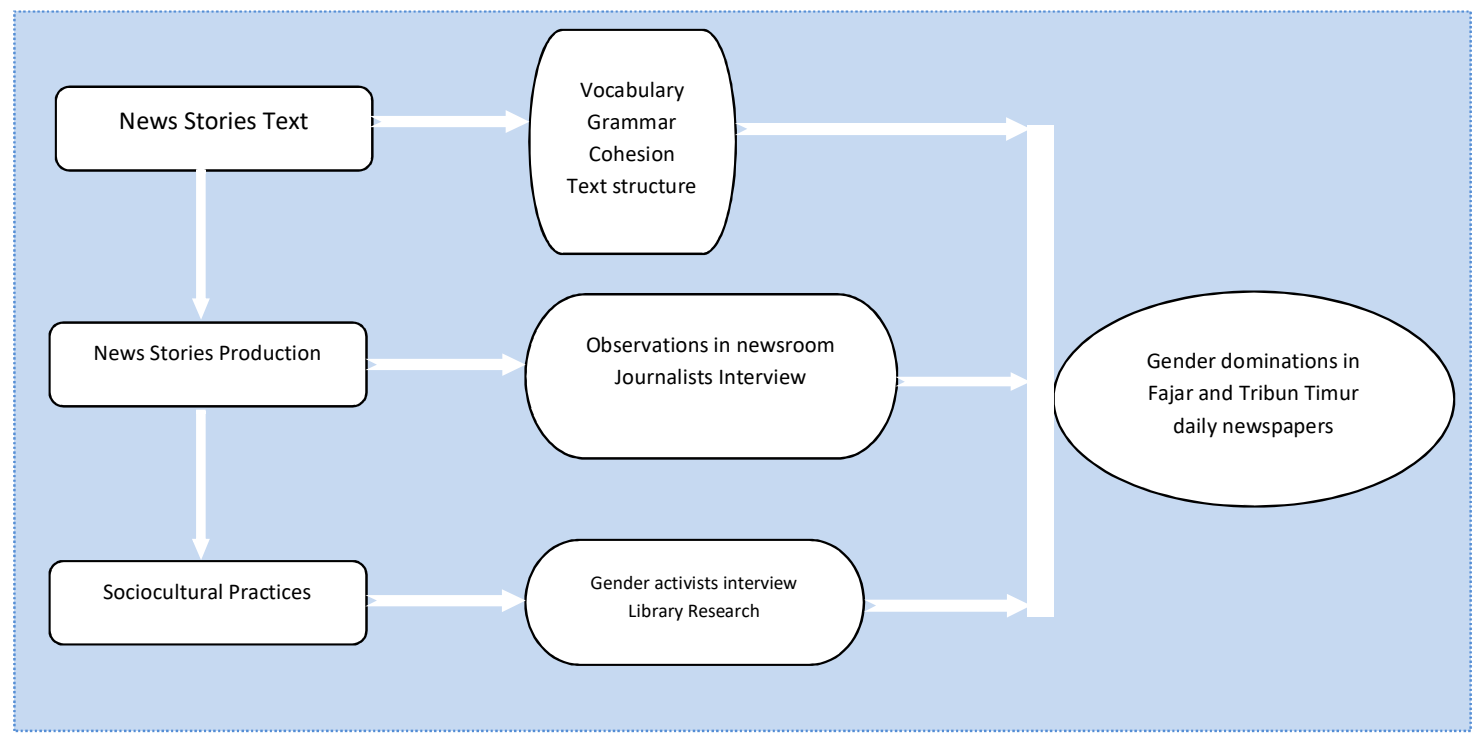




\section{Textual level}

Collecting corpus that is news stories in Fajar and Tribun Timur daily newspapers related to the research. News stories concerning with gender issues namely violence in raping, striking, and prostitutions published in those newspapers are analysed through critical linguistics which consist of vocabulary, grammar, cohesion, and text structure.

\section{$\underline{\text { Discourse Practice level }}$}

Interviews with sources who are relevant to the topic of research and directly observe in newsroom. In this case, male and female journalists that are interviewed are chief editors, editors and reporters in Fajar and Tribun Timur daily newspapers. They are interviewed because of their potentials of making decisions in news-making process.

\section{$\underline{\text { Socio-cultural Practice level }}$}

In socio-cultural practice, gender activists and scientist are interviewed since gender problems are their concerns and their works are related to gender issues published in newspapers. They are Dra. Zohra Andi Baso (Leader of Forum Pemerhati Masalah Perempuan/FPMP), Hj. Sri Rahmi (Secretary of A Commission in DPRD South Sulawesi), Prof. Nurul Ilmi Idrus, M.Sc. Ph.D. (Lecturer of Antropology Department, Hasanuddin University), Dr. Maria E. Pandu, MA (Lecturer of Sociology Department, Hasanuddin University).

For library research, by making reviews of some books related to the topic by reading printed materials such as text books, journals, articles, and other materials which are related to the problems being researched. Then, by directly observing the field of the research.

\section{LITERATURE REVIEW}

\section{Newspapers as Mass Communication Media}

The early part of mass communication age was dominated by printed- media, before the period of broadcasting, television, and the online media. Newspapers - as mass communication media containing news stories, information, and consumer advertisement - have played a key part in expanding and shaping the new public communication institutions.

The most commonly applied measures of content as indicators of quality of local media performance, as mentioned by McQuail (1992) are 1) the relative attention to local news and issues, 2) the use of own news-gathering staff, 3) the degree of attention to matters of local controversy, to criticism and different opinions, 4) the taking of editorial stands on matters of local controversy, 5) advanced information about and coverage of local activities, 6) relative attention to positive local news as against crime, sensation, and disorder news. These are supporting to choose issues to publish specially about gender issue, not only gender inequality but also gender equality.

\section{Gatekeeping theory}

The gatekeeper decides which information will go forward, and which will not. Media gatekeeping shows that decision--making is based on principles of news values, organisational routines, input structure, and common sense.

Gatekeeping theory, at its most basic level, is the idea that there is selectivity in the process of determining what news stories are published or broadcasted. A major point of the theory, as developed by psychologist Kurt Lewin, is that there are forces that can either inhibit or aid the flow of news items through the "gates" (Shoemaker, 1996). One person seldom has complete control over all the gates in the process of disseminating news. The managing editor then talks to the news editor about assigning the story to a reporter. The news editor checks to see which reporters are available to write the story.

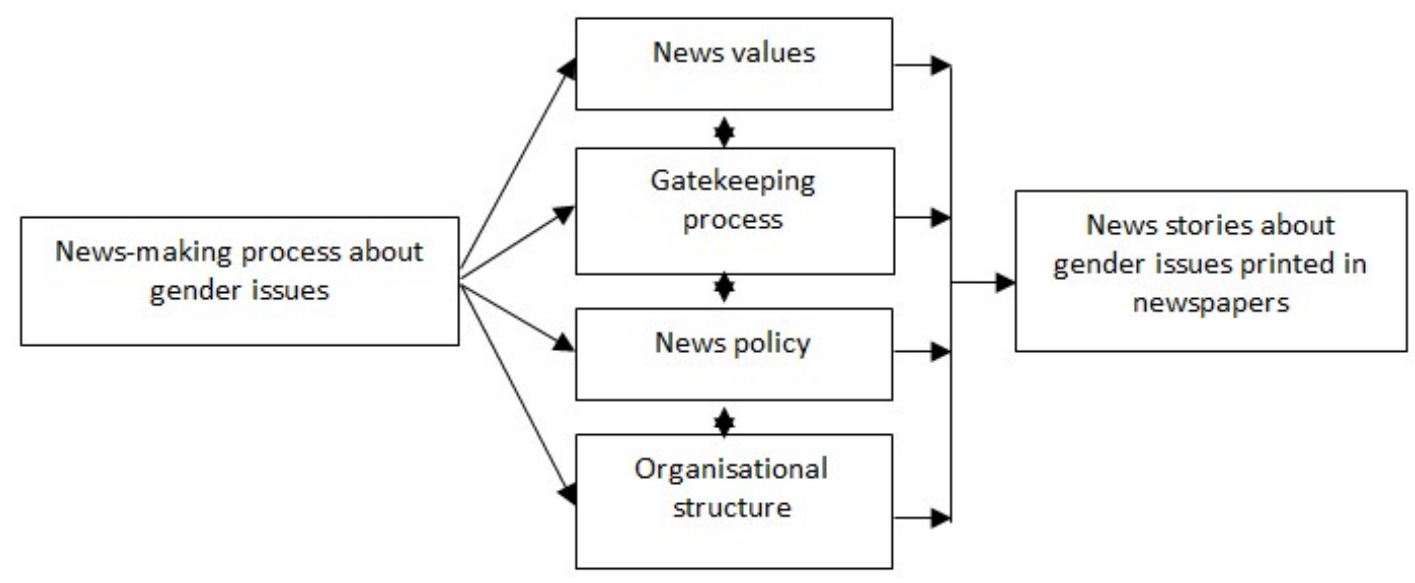




\section{News - Making Process}

\section{News Values}

In news-making process, there are considerations before a news story is printed in newspapers. One of the considerations is news values. The news values which are related to gender issues in this case are threshold - news stories of gender issues which have considerations discussed first in the newsroom before they are published in newspapers, unambiguity - completing news stories about gender issues by using some literature to make the news stories clear-. For example, clippings, dictionaries, and encyclopaedias which are related to the gender issues. Meaningfulness is how meaningful will gender issues appear to receiver of the news story.

Continuity is news stories about gender issues covered as a running story. For example, news story about prostitution is covered in two parts for two days in newspapers. Reference to elite nations is news stories about gender issues in newspapers publishing influenced culture and social life environment. Reference to elite persons is gender issues in news stories which can involve important people like people in government agencies. Consonance is in gathering news stories about gender issues, journalists in Fajar and Tribun Timur report the news stories from news angle they want and considered in their media institutions.

\section{The Newsroom and the News Flows}

Fajar and Tribun Timur have state or area desks, but instead of covering the entire state, they often cover only other communities in the country or in the circulation area of the paper. Coverage of neighbouring communities or other cities in the state is important to newspapers because they are always trying to increase their circulation and advertising base. Fajar and Tribun Timur are morning newspapers called A.M. They report news that breaks on the A.M. cycle, generally from noon to midnight as well as other non-breaking stories. Their news huddles are held in the late afternoon because deadlines are in the evening and the papers are printed and delivered during the night, while most people are sleeping. Beat reporters for A.M. generally work during the day, but many staff members work during the evening (Itule, 1994).

\section{Discourse in the Newsroom}

In news-making decision process, Fajar and Tribun Timur daily newspapers discuss and talk in consideration of news stories of gender issues before they come to conclusion which of the news stories should be published. They argue against particular event or issues and consider effect of the news story for society and wait for acts of government agencies after the news stories are published.

\section{PRESENTATION AND DATA ANALYSIS}

\section{Textual level}

In the textual level, news stories which have been published in Fajar and Tribun Timur daily newspapers concerning raping, striking, and prostitution are analysed by using CDA (Critical Discourse Analysis).

Table 1. Words Indicated as Male Dominating Discourse

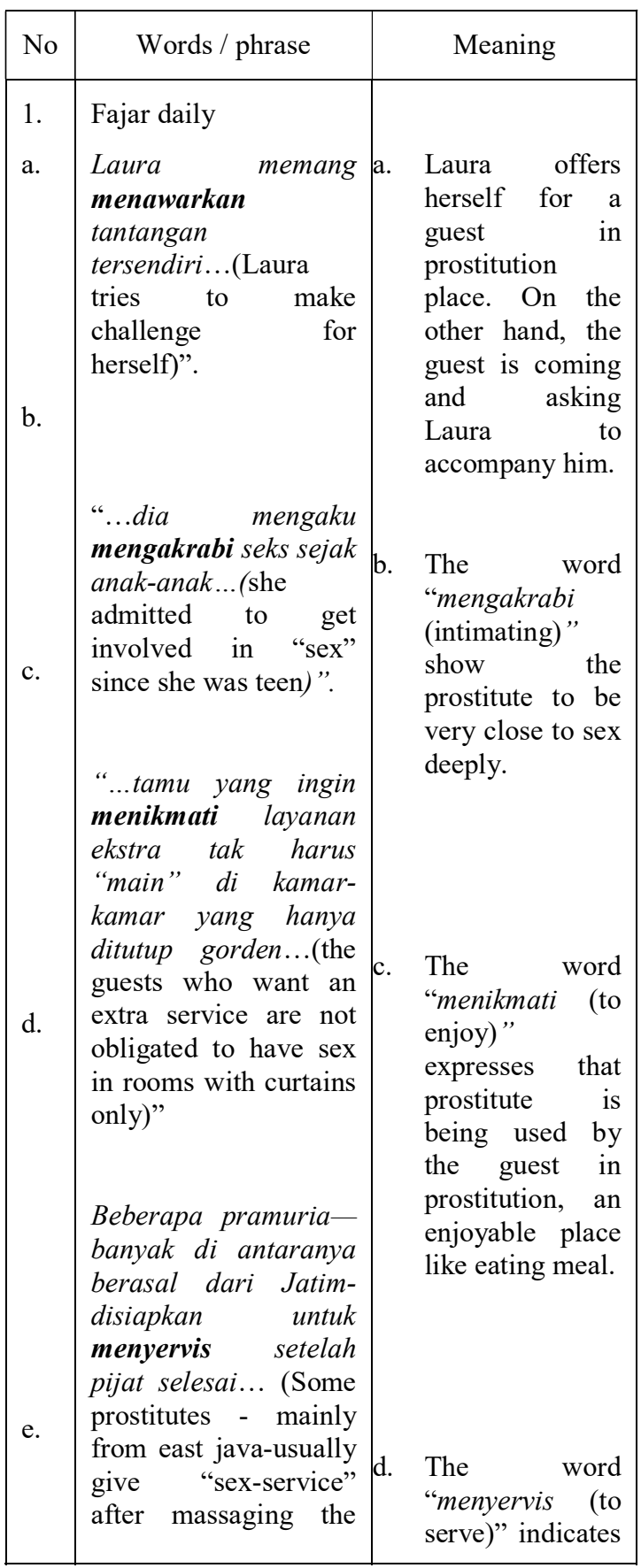




\begin{tabular}{|c|c|c|}
\hline f. & $\begin{array}{l}\text { “...dengan uang itu, } \\
\text { Yulia bisa membiayai } \\
\text { ibunya menunaikan } \\
\text { ibadah haji (with that } \\
\text { money, Yulia can fund } \\
\text { her mother to go for } \\
\text { hajj)”. }\end{array}$ & $\begin{array}{l}\text { that some } \\
\text { prostitutes look } \\
\text { like servants } \\
\text { who will do } \\
\text { anything for the } \\
\text { guest in } \\
\text { prostitution } \\
\text { place. }\end{array}$ \\
\hline a. & $\begin{array}{l}\text { “...Nhr mengancam } \\
\text { membunuh Mus } \\
\text { beserta keluarganya } \\
\text { jika perlakuannya } \\
\text { selama ini diceritakan } \\
\text { kepada orang } \\
\text { lain...(Nhr threatens } \\
\text { to kill Mus with her } \\
\text { family if his behaviour } \\
\text { is revealed to other } \\
\text { people)" }\end{array}$ & $\begin{array}{l}\text { This sentence } \\
\text { makes people } \\
\text { think that a girl } \\
\text { who works as a } \\
\text { prostitute can } \\
\text { use her money } \\
\text { for everything } \\
\text { either in good or } \\
\text { bad ways. }\end{array}$ \\
\hline b. & 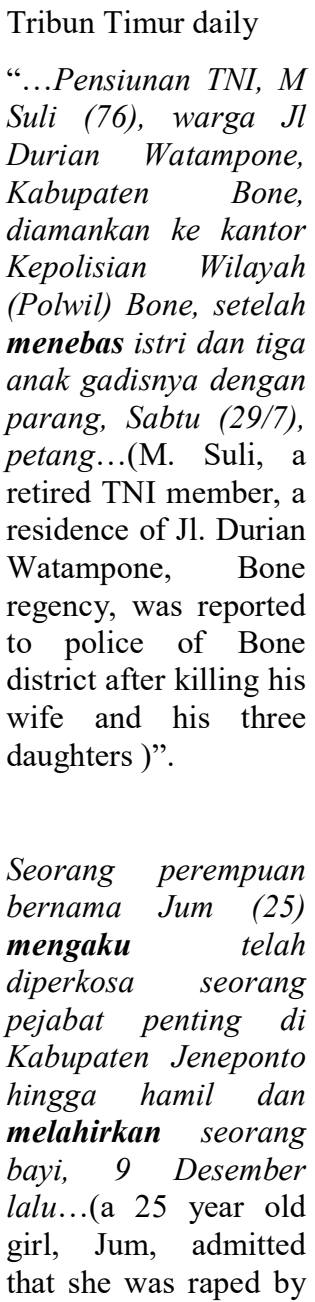 & $\begin{array}{l}\text { a. The word } \\
\text { "menebas (cut } \\
\text { off)" indicate } \\
\text { that a wife and } \\
\text { her daughters } \\
\text { were hurt like } \\
\text { cutting off the } \\
\text { trees. }\end{array}$ \\
\hline
\end{tabular}

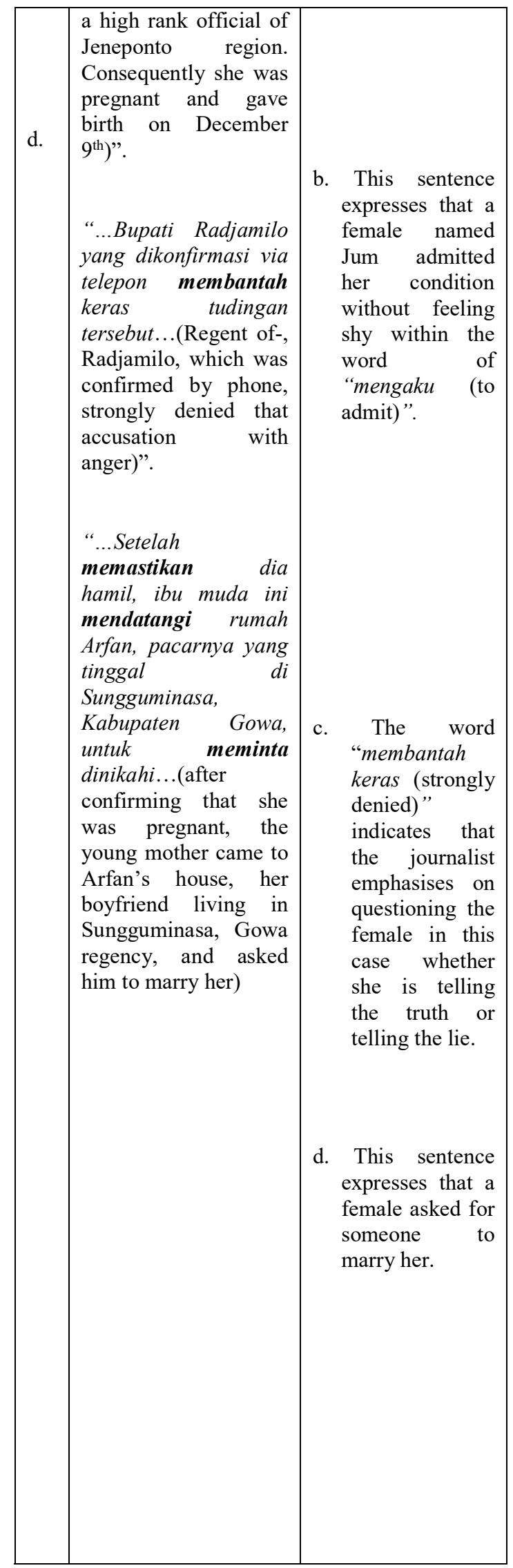




\section{Discourse Practice Level}

Gender issues are very important in newspapers reporting. Not only female or male represented directly in newspapers but also all kind of things related to both of them to read. It is published in news-text and involves many aspects of life. Chief Editor of Fajar daily newspaper, Sukriansyah S.Latief says,

"Dalam perspektif media yang berhubungan dengan perempuan atau lebih jelas dikatakan sebagai yang di baca perempuan adalah hal-hal yang berhubungan dengan perempuan misalnya kesehatan. Perempuan sangat memperhatikan tentang kesehatan, tentang kecantikan tentang pendidikan, politik, budaya, ekonomi dan semua hal (In the perspective of mass media something that is related to gender or something that is read by women is about health. Women pay more attention to health, beauty, education, economic, and others)".

According to him, male is the most important one related to female, and gender is not only talking about female but also something that covers female including male. Supporting the statement above, Nur Alim Djalil, vice chief editor in Fajar daily newspaper says,

"Fajar sendiri memberi prioritas untuk kalangan perempuan terlebih juga isu-isu gender (Fajar itself prioritize the women in the issues of gender)".

News values as the main tendency is more dominant than gender in news-making process. Tribun Timur was designed for family's newspaper. Each news story is intended for family not because of gender perspective. Nevertheless, family is one of the parts in discussing about gender and vice versa.

Actually, female journalists can do the same things as male journalists but people in the media institutions always think about the risks before they send their journalists to report news stories. According to vice editor in chief of Fajar, sometimes female journalist gives the same chance as male journalist to gather news stories but she refuses for her own reasons. According to editor in chief of Tribun Timur, angle of news would be different if news stories were written by male journalist and female journalist.

In the world of press, male and female are the same in gathering news stories and in receiving treatment as well as in the newspaper offices. Supporting that policy, there is no reason for leaving their works. Ramah Praeska, a male journalist in Fajar daily stated that there is no difference between male journalist and female journalist in reporting news. He says,
"Tidak ada perbedaan mencolok perlakuannya sama aja perempuan laki-laki. Itu saja perbedaan piket (The treatment between men and women is the same. They are only different in job shift)".

In news-making process, male and female journalists get involved to share their ideas, their arguments, their complaints, and their inspirations. These chances are always given to the journalist in each meeting. They usually talk according to their own desk, namely sports and entertainment. A female journalist who works more than 10 years in Fajar daily, Sunarti Sain, mentioned about gender inequality in mass media. She says,

"Walaupun dimana-mana di media manapun itu, saya masih melihat perempuan yang menjadi jurnalis perempuan itu masih minoritas karena minoritasnya inilah, mereka sering lebih rentan terkena dampak dari diskriminasi (in most mass media, I still find female journalists as minority. Because they are minority, they usually get discriminated)".

People's appreciation on female in mass media against discrimination still needs an improvement. Female journalist organisation in South Sulawesi is founded as a place to learn many things for female. Those are some reasons why FORWAT (Forum Wartawan Perempuan) was founded in 1991 and has 20-30 members in Makassar.

News stories published in newspapers depends on policy maker in newsroom. Policy maker is the position which female journalist tries to be. This condition gives them special bargaining position for editor. Unfortunately, the number of female editors in newsroom is less than male editors. This rarity is one of the difficulties to show female capability. Sunarti mentioned that journalists in Fajar do not discriminate gender because of the three female journalists who understand gender well. They try to make some alteration to avoid bias in news text. News stories about raping are reported without considering the victim and mass media as the second rapist to the victim. FORWAT wrote letters to some newspapers which have published raping detail and hurt the victim. Besides letters, it could be negotiated face to face with editor in chief of newspapers.

\section{Socio - cultural Practices Level}

Discussing about gender in Makassar and gender in newspapers involves many sectors of life. Female is in domestic space and male is in public space. Zohra A.Baso, Leader of Forum Pemerhati Masalah Perempuan (FPMP) says,

"Akibat perbedaan ini sangat berat untuk perempuan. Kemudian lebih lanjut lagi akibat itu 
semua banyak hal yang tidak merupakan kodrat untuk perempuan dijadikan kodrat untuk perempuan karena kodrat untuk perempuan tidak lebih dari dia punya rahim dia bisa melahirkan, dia punya indung telur secara fisik laki-laki punya alat kelamin berbeda dengan perempuan. (Because of this discrimination it is hard for the women. Further- more, lots of aspects that are not the nature of women but women always make them as their nature. The natures of women are that they have womb, can give a birth, have ovum. While men physically have genitals which is different from women)".

Thus, females have to arrange household, take care of children, and become the second person in family. Males have to be a breadwinner whereas that situation could happen in the contrary if both male and female discuss and agree with their own potential. Sometimes, interesting news stories are ignored because of some important constructions.

Female inequality should be discussed repeatedly to really open the female inequality. Sri Rahmi, a female activist and secretary of a Commission on DPRD Makassar, asserts that there is no job classification between male and female but depends on their capacity. According to her, gender means men too. This has to be noted by news workers in newspapers. If the newspapers are female exploitation, female as an object will be dominant too.

News stories about prostitution, striking, and raping are very important to publish because these are some of the problems in society. Nurul Ilmi Idrus, an academic and gender activist, states,

"Kalau pemberitaan perempuan dalam kasus-kasus kekerasan itu banyak pemberitaan yang menunjuk misalnya kasus pemerkosaan itu kecenderungannya ada pemerkosaan kedua oleh media terhadap korban. Pertama, fotonya dimunculkan dalam keadaan matanya saja yang ditutup sementara kalau mata saja yang ditutup itu masih bisa di deteksi. Kedua, judul-judulnya itu muncul dalam pemberitaan menyudutkan perempuan misalnya digarap, di obok-obok menunjukkan perempuan itu sebagai barang apa di tuliskan dalam pemberitaan-pemberitaan dalam koran (In the news about women in violation cases there is a tendency that the media become the second "rapist" of the victim on that case. First, the picture is published in which only the eyes of the victims being censored, actually the reader still can identify who is the victim. Second, the titles on news discriminate the women. For example it is elaborated clearly, how it seems that the women are like stuff that can be freely shaped by the writers based on what they want)".
The journalists in news-making process have power that forces them to construct the news stories in a male dominated manner from male dominated society paradigm, myth of our society, religion, education, and culture. The journalists could minimise that power from domination by struggling against all forms of discrimination in constructing the news stories. For example, the female journalists sit in editor line in newspapers.

\section{CONCLUSION}

\section{Conclusions}

Gender issues are very important to report, not only female or male represented in newspapers but also all things related to them since those are involving many sectors of social life. News stories of raping, striking, and prostitution published in Fajar and Tribun Timur involve male and female journalists. The news stories expressed in words and sentences represent gender issues. The journalists construct the reality then print them in the news-text form.

In the textual level analysis, both Fajar and Tribun Timur are still using words, phrases, and sentences in news stories text of gender issues with male dominated discourse. In the discourse practice level of analysis, both Fajar and Tribun Timur are the same in news-making process and newsdecisions-making process. Male is still dominating in newsroom. This domination influences the news stories of gender issues which are made and processed in male journalist dominated discourse.

However, there are contradictions between the statements and the facts of the news decisionmaker in those newspapers. They admitted that gender perspective in journalism is an important thing to consider in news-making process. In fact, other considerations like how to make the circulation of the newspapers is still more important. They also admitted that they made priority and gave opportunity for female expressions and avoided gender discrimination in the newspapers. In fact, although the news stories are made by revictimising the victim by the newspapers themselves, female journalists are still considered in gathering news stories in conflict or dangerous area.

In socio-cultural discourse practice level of analysis, according to gender activists, Fajar and Tribun Timur are getting better than before in reporting the news stories of gender issues. However, those daily newspapers can be trapped in an exploitation of female's body and gender discrimination with inclined female as an object in the news stories.

\section{Suggestions}


The representative of female in Fajar and Tribun Timur daily newspapers still needs much attention, whether as female's voices printed in the newspapers. For gender against discrimination, the journalists have to understand about gender and working through their portion with their high responsibility.

\section{BIBLIOGRAPHY}

Denhiere, G., \& Jean, P. R. (1991). Text and Text Processing. North Holland : Elsevier Science.

Eriyanto. (2001). Analisis Wacana. Yogyakarta: PT. LKIS Pelangi Aksara.

Fairclough, N. (1992). Discourse and Text: Linguistic and Intertextual Analysis within Discourse Analysis. London : Lancaster University.

(2001). Language and Power (2 $2^{\text {nd }}$ ed). England: Longman.

First, A. (2002). All Women Should Cry: The Presentation of Women in Foreign News. Walter De Gruyter.

Ibrahim, S., I., \& Hanif, S. (1998). Wanita dan Media. Bandung: PT. Remaja Rosdakarya.

Itule, D., B., \& Douglas A. A. (1994). News Writing and Reporting for Today's Media $\left(3^{\text {rd }}\right.$ ed). USA: McGraw-Hill, Inc.

Kriyantono, R. (2006). Teknik Praktis Riset Komunikasi. Jakarta: Kencana.

Lewis, G., \& Christina, S. (1994). Critical Communication. Australia: Prentice Hall.

Lloyd, F., \& Ross, H. (2004). Gender,Conflict \& Journalism. France: Unesco Communication and Information Sector.

Mcquail, D. (1992). Media Performance. London: Sage Publications.

Mosse, C., J. (1996). Gender \& Pembangunan. Yogyakarta: Pustaka Pelajar.

Mulyana. (2005). Kajian Wacana. Yogyakarta: Tiara Kencana.

Mulyana, D. (2003). Metodologi Penelitian Kualitatif. Bandung: PT. Remaja Rosdakarya.

Perempuan dan Media. Jurnal Perempuan, 2003 (28). Jakarta: Yayasan Jurnal Perempuan.
Schudson, M. (1989). The Sociology of News Production. San Diego: University of California.

Subono, I. (2003). Menuju jurnalisme yang berperspektif gender. Jurnal Perempuan, 28, 55-66.

Teo, P. (2000). Racism in the News: A Critical Discourse Analysis in News Reporting into Australian Newspaper. London: Sage Publications.

Tuchman, G. (1978). Making News. New York: The Free Press. 